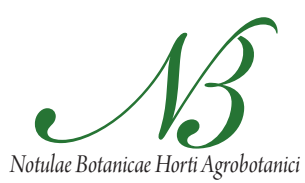

Cluj-Napoca

\title{
Juglone Content in Leaf and Green Husk of Five Walnut (Juglans regia L.) Cultivars
}

\author{
Sina COSMULESCU ${ }^{1}$, Ion TRANDAFIR ${ }^{2}$, Gheorghe ACHIM ${ }^{13}$, Adrian BACIU ${ }^{1}$ \\ ${ }^{1}$ University of Craiova, Faculty of Horticulture, 13 A. I. Cuza, 200585, Craiova, Romania; sinacosmulescu@hotmail.com \\ ${ }^{2}$ University of Craiova, Faculty of Chemistry, 107 Calea București, 200529, Craiova, Romania; nelutrandafir@yahoo.com \\ ${ }^{3}$ University of Craiova, SCDP Valcea, 464 Calea lui Traian, 240273, Râmnicu Vâlcea, Romania; gheorgheachim555@yahoo.com
}

\begin{abstract}
Juglone (5-hydroxy-1,4-napthoquinone) is a chemical compound released by walnut trees that can be toxic for surrounding plant species. In the present study, juglone was identified in leaves and green husk in five walnut cultivars: 'Germisara', 'Jupanesti', 'Franquette', 'Vina, 'Valcor' by using high performance liquid chromatography (HPLC-RP). Juglone was found predominant in green husk (average value of cultivars is about $31.308 \mathrm{mg} / 100 \mathrm{~g}$ ). Significant differences in contents of identified juglone were observed among cultivars that ranged from 20.56 to $42.78 \mathrm{mg} / 100 \mathrm{~g}$ for green husk, and 5.42 to $22.82 \mathrm{mg} / 100 \mathrm{~g}$ for leaves. It was also found that walnut green husk and leaves represent the most important source of walnut phenolics.
\end{abstract}

Keywords: allelopathy, HPLC-RP, Juglans regia, juglone

\section{Introduction}

Juglone, also called 5-hydroxy-1,4-napthoquinone, is an organic compound and occurs naturally in leaves, roots, husks, and bark of plants in Juglandaceae family, particularly in black walnut (Juglans nigra) (Ercisli and Turkkal, 2005). Sun et al. (2006) reported that the amounts of juglone $J$. mandshurica were in order of green peel $>$ leaves $>$ bark.

Juglone is an example of allelopathic compound, a substance that is synthesized by one type of plant and affects the growth of another. Corn and soybean are sensitive to juglone (Shibu and Gillespie, 1998). Juglone has inhibitory effects on strawberry plants (Ercisli et al., 2005). Kocacaliskan and Terzi (2001) demonstrated that both juglone and walnut leaf extracts inhibit germination and seedling growth in several plant species (watermelon, tomato, garden crest and alfalfa). Similar results were indicated by Terzi (2008). Inhibition is expressed by reduced intensity of photosynthesis and respiration (Hejl et al., 1993). Elongation, fresh and dry weights of muskmelon seedlings-all were enhanced by juglone in intact seeds (Kocaçaliskan et al., 2008). Alcoholic extracts of walnut leaves showed allelopathic activity against lettuce seed (Zhang et al., 2008).

As regards the occurrence and fate of phytotoxin juglone in alley soils under black walnut trees, showed that juglone accumulation in low fertility soils is plausible, and may still be worthy of consideration in management of alley agroforestry systems (Kiparski et al., 2007). Juglone is occasionally used as herbicide. On the herbicidal effect of juglone, Topal et al. (2007) showed that juglone is a potent inhibitor of growth of weeds and therefore it can be evaluated as herbicide for future weed management strategies. Juglone and some other phenolics may be involved into the defense mechanism against walnut bacterial blight (Solar et al., 2005) as well. Sun et al. (2007) showed insecticidal activities and active components of alcohol extract of green peel of J. mandshurica on Lymantria dispar $\mathrm{L}$.

Previously seasonal changes of juglone in leaves of black walnut showed a linear decrease over growing season (Coder, 1983). Measurements of seasonal distribution of juglone among various tissues of pecan revealed that the highest concentrations occurred in leaflets in June and in nuts in September (Borazjani et al., 1985). The cultivar belongs to J. regia has influence on content of phenolic compounds (Cosmulescu et al., 2010a). Polyphenols have been used in walnut also in studies of diversity (Cosmulescu et al., 2010b). Previous researches showed that Romanian walnut cultivars proved to be important sources of nutritive elements (Cosmulescu et al., 2009).

The aim of this work was to determine juglone content (both in leaves and green husk) in walnut cultivars grown in Romania.

\section{Materials and methods}

\section{Materials}

Extraction, identification and quantification of free polyphenols were carried out in leaves and green husk of mature fruits of five walnut cultivars ('Germisara', 'Jupanesti', 'Franquette,' 'Vina', 'Valcor'). Samples were collected at the beginning of September (towards the end of vegetation period). They were taken from the experimen- 
238

tal plantation in Râmnicu Vâlcea (Romania) research station (located at $45^{\circ} 6^{\prime} 17^{\prime \prime}$ northern latitude with meridian $24^{\circ} 22^{\prime} 21^{\prime \prime}$ eastern longitude; altitude of 240-260 m, average yearly temperature of $9^{\circ} \mathrm{C}$, and average yearly rainfall of $840 \mathrm{~mm}$ ). Sampling was carried out at the beginning of September, and they were preserved at $-40^{\circ} \mathrm{C}$ until analysis.

\section{Methods}

Samples, made of finely chopped in amount of $500 \mathrm{mg}$ were introduced in conical containers together with $20 \mathrm{ml}$ methanol with $1 \%$ BHT (2,6-di-tert-butyl-4-methylphenol), and were kept at $25^{\circ} \mathrm{C}$ temperature in ultrasound bath for 40 minutes. Extracts were separated by centrifugation at $1200 \mathrm{~g}$. Supernatants were filtered through polyamide membrane with pores diameter of $0.22 \mu \mathrm{m}$ and stored at $-20^{\circ} \mathrm{C}$.

Reverse phase high performance liquid chromatography (HPLC-RP) was used to identify and quantify free polyphenols HPLC-SURVEYOR Plus (Thermo Electron), configured with a quaternary pump and a degasser of incorporated vacuum SRVYR-LPMPP, thermostatic autosampler Peltier SRVYR-ASP, a diode array detector SRVYR-PDA5P, column Chromsep HPLC (250x4.6 $\mathrm{mm}$, Hypersil 5 BDS) under the control of CHROMQUEST software.

\section{Chemicals}

The standards was juglone (5-hydroxy-1,4-naphthoquinone; Sigma Aldrich, USA). Acetonitrile (Baker, USA), acetic acid (Merck, Germany) and ultrapure water (obtained with a SG-Water system) were used as mobile phase for HPLC. Solutions were obtained by dissolving juglone standard in methanol (Merck). Mobile phase was filtered through polyamide membrane having $0.2 \mu \mathrm{m}$ pore diameter and degassed with the help of ultrasound bath type DK 102p Bandelin. Before injecting, the samples were filtered through nylon syringe filters CRS having $0.45 \mu \mathrm{m}$ pore diameter.

\section{Chromatographic conditions}

Chromatographic conditions were set based on Schieber et al. (2001) with minor changes. A gradient was applied, where solvent $A$ is water with $5 \%(\mathrm{v} / \mathrm{v})$ acetic acid, solvent B acetonitrile: water 50:50 (v/v) with $0.5 \%$ acetic acid. Samples and column were thermostated at $25^{\circ} \mathrm{C}$, the eluent flow was $1 \mathrm{ml} / \mathrm{min}$, while the injection volume was $20 \mu \mathrm{l}$. Detection was followed at $420 \mathrm{~nm}$. Gîrzu et al. (1998), by using the method high-performance liquid chromatographic, has determined juglone in fresh walnut leaves (juglone was detected by visible absorbance at 420 $\mathrm{nm})$.

\section{Statistical analysis}

Descriptive statistics of data were analyzed with the Microsoft Excel. All data were expressed as means \pm standard deviations of triplicate measurements.

\section{Results and discussion}

Juglone, a well-known component of walnut, is found in considerable amounts in all green and growing parts of trees and unripe hulls of the fruit (Prasad, 2003). Hence, the juglone content of fresh leaves and green husk samples was quantified by reverse phase high performance liquid chromatography (HPLC-RP), according to its retention time and spectral characteristics and results are shown in Tab. 1 and 2.

Tab.1. Retention time $(\operatorname{mean} \pm S D, \min )^{*}$ of juglone compounds of leaves and green husk of walnut cultivars

\begin{tabular}{lccc}
\hline \multirow{2}{*}{ Phenolic compound } & \multicolumn{2}{c}{ Rt (Retention time, min.) } \\
\cline { 2 - 4 } & \multicolumn{2}{c}{ Mean \pm SD } & Limits \\
\hline \multirow{2}{*}{ Juglone } & leaves & $48.79 \pm 0.28$ & $48.57-49.11$ \\
\cline { 2 - 4 } & green husk & $48.77 \pm 0.12$ & $48.55-49.08$ \\
\hline
\end{tabular}

${ }^{*}$ Values are expressed as mean of five determinations for each sample; $\mathrm{SD}=$ standard deviation

Tab. 2. Juglone content (mean $\pm S D, m g / 100$ g probe) $)^{*}$ of walnut cultivars

\begin{tabular}{ccc}
\hline \multirow{2}{*}{ Cultivars/Compound } & \multicolumn{2}{c}{ Juglone $(\mathrm{mg} / 100 \mathrm{~g})$} \\
\cline { 2 - 3 } & green husk & leaves \\
\hline 'Germisara' & $27.91 \pm 1.11$ & $22.82 \pm 0.24$ \\
'Jupanesti' & $42.78 \pm 0.95$ & $5.44 \pm 0.15$ \\
'Franquette' & $40.34 \pm 1.23$ & $15.21 \pm 0.43$ \\
'Vina' & $20.56 \pm 0.87$ & $12.55 \pm 0.81$ \\
'Valcor' & $24.93 \pm 0.92$ & $5.42 \pm 0.61$ \\
Mean & 31.308 & 12.289 \\
Range & 22.211 & 17.406 \\
Standard Deviation & 8.72 & 7.308 \\
\hline
\end{tabular}

${ }^{*}$ Values were expressed as mean of three determinations for each sample

For juglone retention time was $48.79 \mathrm{~min}$ for walnut leaves, and $48.77 \mathrm{~min}$ for fruit green husk and differences were significant (Fig. 1 and 2).

Juglone content in green husk was higher in all walnut cultivars than in walnut leaf samples (Tab. 2). Results were similar to literature. According to data in the literature, juglone is found in considerable amounts in all green and growing parts of trees and unripe hulls of nut (Prasad, 2003).

Average content in green husk was $31.308 \mathrm{mg} / 100 \mathrm{~g}$ (variation limits were within 20.56 and $42.78 \mathrm{mg} / 100 \mathrm{~g}$ ). As regards determination of quantitative juglone in green walnut fruits, Velickovic et al. (2007) showed that juglone quantity was the highest in fruits weighing between 4.5 $\mathrm{g}$ and $6.5 \mathrm{~g}$ (harvesting time around June $1^{\text {st }}$ ), and varied from $209.60 \mathrm{mg}$ up to $735.00 \mathrm{mg}$.

At the end of vegetation period, low quantities of juglone also reported by other authors in English walnut (Solar et al., 2005). Also, regarding the seasonal changes, juglone showed a linear decrease over growing season in black walnut (Coder, 1983). 


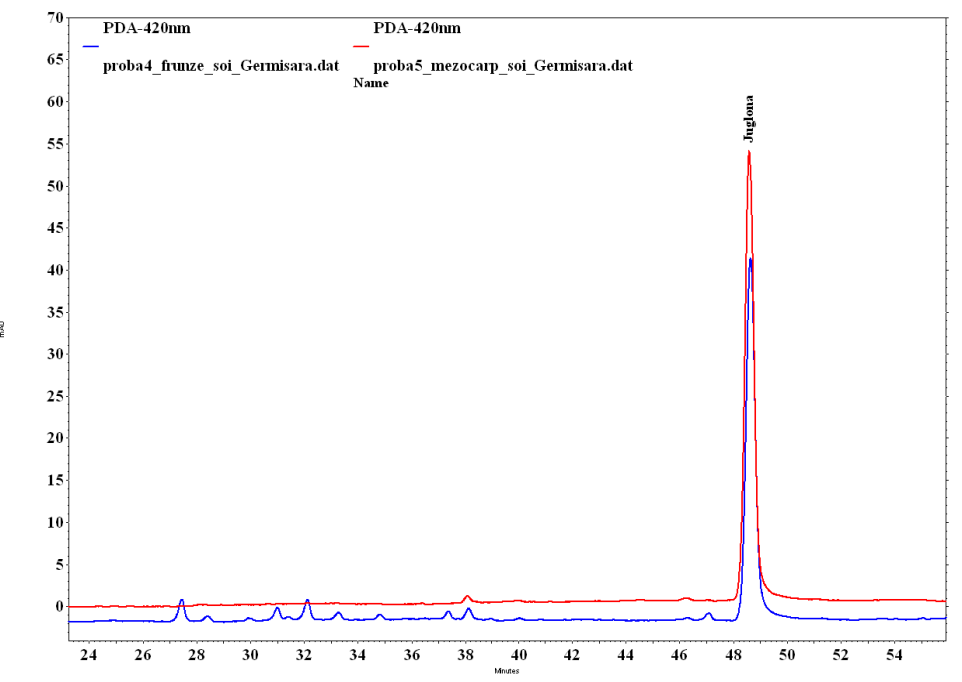

Fig. 1. HPLC-RP walnut leaf (blue curve) and green husk (red curve) phenolic profile (cv. 'Germisara'). Detection at $420 \mathrm{~nm}$ : juglone

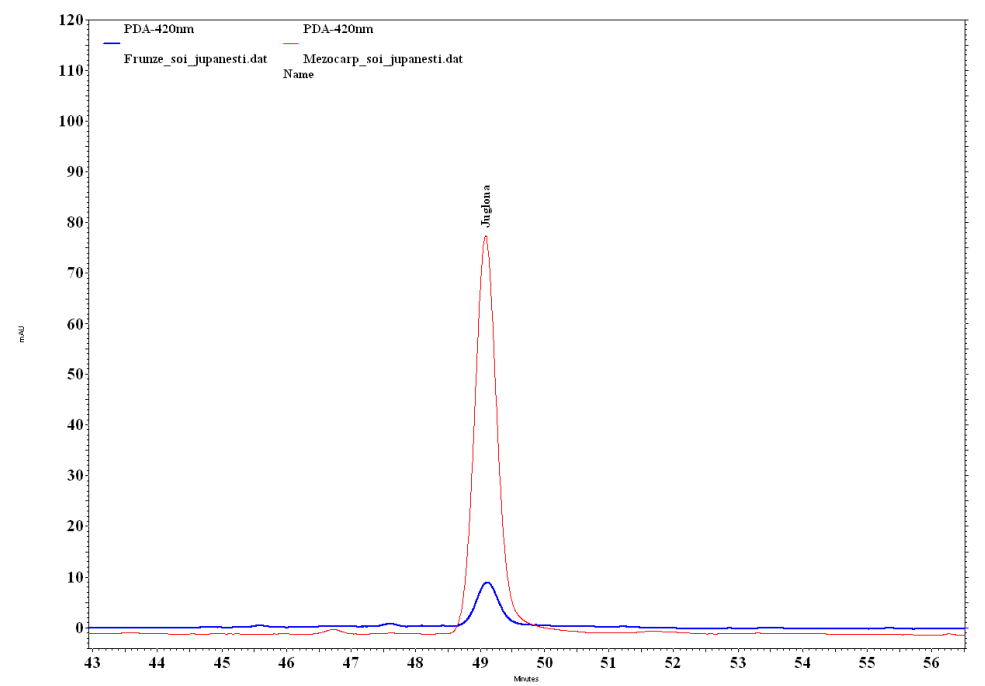

Fig. 2. HPLC-RP walnut leaf (blue curve) and green husk (red curve) phenolic profile (cv. 'Jupanesti'). Detection at $420 \mathrm{~nm}$ : juglone

The average content of juglone in the leaves of the five cultivars was $12.289 \mathrm{mg} / 100 \mathrm{~g}$. Differences between the cultivars, in terms of juglone, were $17.406 \mathrm{mg} / 100 \mathrm{~g}$. In accordance with literature (Solar et al., 2005; Colaric et al., 2005), juglone content of leaf varied from one cultivar to another $(5.42-22.82 \mathrm{mg} / 100 \mathrm{~g})$. Willis (2000), showed that potential juglone abundance estimated in walnut leaves, hulls, and roots ranges from less than $0.1 \%$ to as much as 5\% dry weight-basis, depending on the growing season and extraction techniques used.

The lowest variability was recorded in walnut leaves, reflected by standard deviation (7.308) recorded. Differences between cultivars were significant; juglone content recorded a higher coefficient of variation. In terms of walnut leaves, the differences between cultivars were 17.406 $\mathrm{mg} / 100 \mathrm{~g}$, the highest content was recorded in 'Germisara' cultivar. For green husk, variability was higher, reflected by standard deviation value (8.72); highest content was recorded in 'Jupanesti' cultivar $(42.78 \mathrm{mg} / 100 \mathrm{~g})$, (Tab. 2).

In conclusion, the results indicated that mature leaves and green husk in walnut plantations were a source of juglone compounds. In accordance with literature (Solar $e t$ al., 2005; Amaral et al., 2004), juglone was identified in all cultivars, but there were differences among cultivars regarding content and between materials showed. In general juglone content is higher in green husk of walnut fruits. Although their limited use, mature leaves and green husk of walnuts were by-products in walnut plantations and they could be a source of phenolic compounds. Leaf extracts could be used as an easily accessible source of natural antioxidants. Also, decomposition of walnut leaves (after falling to the ground) and green husk brings into soil and 
240

resulted different amounts of phenols with allelopathic effect.

\section{Acknowledgments}

This work was supported by CNCSIS-UEFISCSU, project number PNII-IDEI code 430 /2008.

\section{References}

Amaral JS, Seabra RM, Andrade PB, Valentao P, Pereira JÁ, Ferreres F (2004). Phenolic profile in the quality control of walnut (Juglans regia L.) leaves. Food Chemistry 88:373379.

Borazjani A, Graves CH, Hedin PA (1985). Occurrence of juglone in various tissues of pecan and related species. Physiology and Biochemistry 75(12):1419-1421.

Coder KD (1983). Seasonal changes of juglone potential in leaves of black walnut (Juglans nigra L.). Journal of Chemical Ecology 9(8):1203-1212.

Colaric M, Veberic R, Solar A, Hudina M, Štampar F (2005). Phenolic acids, syringaldehyde, and juglone in fruits of different cultivars of Juglans regia L. J Agric Food Chem 53(16):6390-6396.

Cosmulescu S, Baciu A, Achim G, Botu M, Trandafir I (2009). Mineral Composition of Fruits in Different Walnut (Juglans regia L.) Cultivars. Notulae Botanicae Horti Agrobotanici Cluj-Napoca 37(2):156-160.

Cosmulescu S, Trandafir I, Achim G, Botu M, Baciu A, Gruia M (2010a). Phenolics of Green Husk in Mature Walnut Fruits. Notulae Botanicae Horti Agrobotanici Cluj-Napoca 38(1):53-56.

Cosmulescu S, Baciu A, Botu M, Achim G, Trandafir I, Gruia M (2010b). Polyphenols - Potential Markers For Determining The Genetic Diversity In Walnut. Lucrari Stiintifice Universitatea Agrara de Stat din Moldova, Facultatea de Horticultura 24(1):19-25.

Ercisli S, Esitken A, Turkkal C, Orhan E (2005). The allelopathic effects of juglone and walnut leaf extractson yield, growth, chemical and PNE compositions of strawberry cv. 'Fern'. Plant Soil Environ 51(6):283-287.

Ercisli S, Turkkal C (2005). Allelopathic effects of juglone and walnut leaf extracts on growth, fruit yield and plant tissue composition in strawberry cvs. 'Camarosa' and 'Sweet Charlie. Journal of Horticultural Science and Biotechnology $80(1): 39-42$.

Girzu M, Fraisse D, Carnat AP, Carnat A, Lamaison JL (1998). High-performance liquid chromatographic method for the determination of juglone in fresh walnut leaves. Journal of Chromatography A 805(1-2):315-318.

Hejl AM, Einheliig FA, Rasmussen J (1993). Effects of juglone on growth, photosynthesis and respiration. Journal of Chemical Ecology 19:559-568.
Kiparski GR, Lee LS, Gillespie AR (2007). Occurrence and Fate of the Phytotoxin Juglone in Alley Soils under Black Walnut Trees. J Environ Qual 36:709-717.

Kocacaliskan I, Terzi I (2001). Allelophatic effects of walnut leaf extracts and juglone on seed germination and seedling growth. Journal of Horticultural Science and Biotechnolgy 7:436-440.

Kocaçaliskan I, Turan E, Terzi I (2008). Juglone effects on seedling growth in intact and coatless seeds of muskmelon. African Journal of Biotechnology 7(24): 4446-4449.

Prasad RBN (2003). Walnuts and pecans, p. 6071-6079. In: Caballero B, Trugo LC, Finglas PM (Eds.). Encyclopaedia of food sciences and nutrition. Academic Press, London.

Shibu J, Gillespie AR (1998). Allelopathy in black walnut (Juglans nigra L.) alley cropping. II. Effects of juglone on hydroponically grown corn (Zea mays L.) and soybean (Glycine $\max$ L. Merr.) growth and physiology. Plant and Soil 203:199-205.

Schieber A, Keller P, Carle R (2001). Determination of phenolic acids and flavonoids of apple and pear by high-performance liquid chromatography. Journal of Chromatography A 910(2):265-273.

Solar A, Colaric M, Hudina M, Štampar F (2005). Phenolic content of walnut fruit as affected by cultivar and developmental stage. Acta Hort 705:231-240.

Sun M, Song Z, Fang G (2006). Extraction and determination of total flavonoid and juglone in Juglans mandshurica Maxim. Chem Ind Forest Prod 26(2):93-95.

Sun M, Wang Y, Song Z, Fang G (2007). Insecticidal activities and active components of the alcohol extract from green peel of Juglans mandshurica. Journal of Forestry Research $18(1): 62-64$.

Terzi I (2008). Allelopathic effects of Juglone and decomposed walnut leaf juice on muskmelon and cucumber seed germination and seedling growth. African Journal of Biotechnology 7(12):1870-1874.

Topal S, Kocacaliskan I, Arslan O, Tel AZ (2007). Herbicidal effects of juglone as an allelochemical. Phyton 46(2):259269.

Velickovic M, Vulic T, Oparnica C, Radivojevic D, Djordjevic B, Tesevic V, Jadranin M (2007). The determination of quantitative jugolone [i.e. juglone] content dynamics and the antioxidant activity in the extract of green walnut (Juglans regia L.) fruits. Journal of Scientific Agricultural Research 68(241):59-68

Willis RJ (2000). Juglans spp., juglone and allelopathy. Allelopathy Journal 7:1-55

Zhang H, Gao JM, Liu WT, Tang JC, Zhang XC, Jin ZG, Xu YP, Shao MA (2008). Allelopathic substances from walnut (Juglans regia L.) leaves. Allelopathy Journal 21(2):354362. 